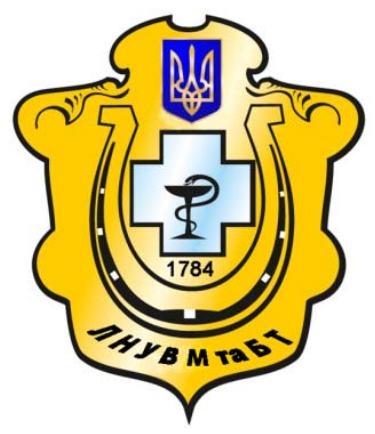

Науковий вісник Львівського національного університету ветеринарної медицини та біотехнологій імені С.3. Гжицького

Scientific Messenger of Lviv National University of Veterinary Medicine and Biotechnologies named after S.Z. Gzhytskyj

doi:10.15421/nvlvet7513

ISSN 2519-268X print

ISSN 2518-1327 online

$\underline{\text { http://nvlvet.com.ua/ }}$

\title{
Розрахунок рецептур та розробка технологічної схеми виробництва альбумінового сиру «Урда» для промислових підприємств
}

\author{
О.Я. Білик, Г.В. Дроник, Н.Б. Сливка, Б.В. Гутий \\ bilyk_oksi@ukr.net
}

Львівський національний університет ветеринарної медицини та біотехнологій імені С.3. Гжиџького,
вул. Пекарська, 50, м. Львів, 79010, Украйна;

Виробництво сиру «Урда» у промислових умовах може зайняти вагоме місие в асортиментному ряді молочних продуктів, оскільки сир має високі біологічну цінність та смакові якості. Одержання сиру «Урда» залежить від кількості свіжоі

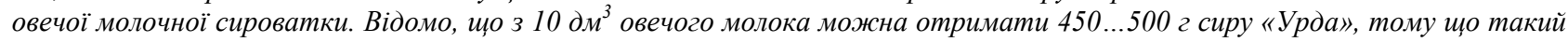
продукт виготовляють виключно з овечої сироватки. Він є значно дорожчим порівняно з іншими видами сиру. Однак, використавши як додаткову сировину сироватку з коров'ячого молока, можна значно здешевити вартість готового продукту, а також раціонально використати вторинну сировину, щзо утворюється при виробництві сирів із коров'ячого і овечого молока.

У статті запропоновано науково обтрунтовані рецептури для виробництва альбумінового сиру «Урда»; розроблено технологічну схему виробництва продукту. Технологія альбумінового сиру «Урда» пройшла промислову апробацію на ПАТ «Ковельмолоко», м. Ковель. На продукт розроблено технічні умови ТУУ 01.4-00492990-004:2014.

В основі розрахунку рещептур альбумінового сиру «Урда» було проведення експериментальних досліджень, які дали можливість визначити рачіональне співвідношення овечої та коров'ячої сироваток для виробництва продукту. Встановлено, що для виробництва сиру «Урда» можна використовувати сумімі сироваток (овеча:коров'яча) у співвідношеннях 1:1 та 3:1. Розроблена технологія альбумінового сиру «Урда» може бути впроваджена на молокопереробному підприємстві, де налагоджено випуск твердих сичужних сирів і розсольного сиру бринза. Впровадження нової технології не потребує великих виробничих площ, дороговартісного обладнання і додаткового переоснащення виробництва. Виробництво альбумінового сиру «Урда» може бути реалізовано на діючих виробничих площах паралельно з випуском основної продукції.

Ключові слова: овеча сироватка, коров'яча сироватка, альбуміновий сир «Урда», речептура, технологічна схема.

\section{Расчет рецептур и разработка технологической схемы производства аль- буминового сыра «Урда» для промышленных предприятий}

\author{
О.Я. Билык, В.Г. Дронык, Н.Б. Слывка, Б.В. Гутый \\ bilyk_oksi@ukr.net
}

\begin{abstract}
Львовский национальный университет ветеринарной медицины и биотехнологий имени С.3. Гжицекого, ул. Пекарская, 50, г. Львов, 79010, Украина;
\end{abstract}

\begin{abstract}
Производство сыра «Урда» в промышленных условиях может занять важное место в ассортиментном ряде молочных продуктов, поскольку сыр имеет высокие биологическую ценность и вкусовые качества. Получение сыра «Урда» зависит от количества свежей овечьей молочной сыворотки. Известно, что с 10 дм $^{3}$ овечьего молока можно получить $450 \ldots 500$ г сыра «Урда», потому что такой продукт изготавливают исключительно из овечьей сыворотки. Он значительно дороже по сравнению с другими видами сыра. Однако, использовав как дополнительное сырье сыворотку из коровьего молока, можно значительно удешевить стоимость готового продукта, а также рачионально использовать вторичное сырье, образуюшиеся при производстве сыров из коровьего и овечьего молока.

В статье предложенные научно обоснованные рецептуры для производства альбуминового сыра «Урда»; разработана технологическая схема производства продукта. Технология альбуминового сыра «Урда» прошла промыциенную апробацию на ОАО «Ковельмолоко», г. Ковель. На продукт разработаны технические условия ТУ 01.4-00492990-004: 2014.
\end{abstract}

\section{Citation:}

Bilyk, O.Ya., Dronyk, G.V., Slyvka, N.B., Gutyj, B.V. (2017). Calculation of recipes and development of technological production schemes of albumin cheese «Urda» for industry. Scientific Messenger LNUVMBT named after S.Z. Gzhytskyj, 19(75), 65-71. 
В основе расчета рецептур альбуминового сыра «Урда» было проведение экспериментальных исследований, которые позволили определить рациональное соотночение овечьей и коровьей сыворотки для производства продукта. Установлено, что для производства сыра «Урда» можно использовать смеси сывороток (овечья : коровья) в соотночениях 1:1 и 3:1.

Разработанная технология альбуминового сыра «Урда» может быть внедрена на молокоперерабатьвающем предприятии, где налажен выпуск твердых сычужных сыров и рассольного сыра брынза. Внедрение новой технологии не требует больших производственных площадей, дорогостоящего оборудования и дополнительного переоснащения производства. Производство альбуминового сыра «Урда» может быть реализовано на действующих производственных площадях параллельно с выпуском основной продукции.

Ключевые слова: овечья сыворотка, коровья сыворотка, альбуминовый сыр «Урда», рецептура, технологическая схема.

\title{
Calculation of recipes and development of technological production schemes of albumin cheese «Urda» for industry
}

\author{
O.Ya. Bilyk, G.V. Dronyk, N.B. Slyvka, B.V. Gutyj \\ bilyk_oksi@ukr.net
}

\begin{abstract}
Lviv national university of veterinary medicine and biotechnologies named after S. Gzhytskyj, Pekarska Str., 50, Lviv, 79010, Ukraine;
\end{abstract}

Production of «Urda» cheese in industrial conditions can take a significant place in the assortment of dairy products as the cheese has a high biological value and taste. The amount of obtaining «Urda» cheese depends on the amount of fresh sheep's milk whey. It is known that from $10 \mathrm{dm} 3$ of sheep's milk, 450 ... $500 \mathrm{~g}$ of «Urda» cheese can be made because the product is made exclusively from sheep whey. It is much more expensive compared to other types of cheese. However, using as additional raw material whey from cow's milk the cost of the finished product can be significantly reduced. The recycled materials from cow and sheep milk are also effectively utilized.

The article deals with the scientific and reasonable recipes for the production of albumin «Urda» cheese, the technological scheme of its production. Technology of albumin «Urda» cheese was tested on an industrial PJSC "Kovelmoloko» in Kovel. Product specifications TU 01.4-00492990-004: 2014 have been developed.

The basis of recipes calculation of «Urda» cheese was experimental research that made it possible to determine the ratio of sheep and bovine whey to produce the product. It has been found that for «Urda» cheese can be used a mixture of whey (sheep: cow) in the ratio of $1: 1$ and $3: 1$.

The technology of albumin «Urda» cheese can be applied to dairy plants where hard rennet cheese and cottage cheese brynza are produced. The introduction of new technology does not require large production areas are as expensive additional equipment and modernization of industry. Production of albumin «Urda» cheese can be implemented on existing production facilities parallelly with the output of the main products.

Key words: sheep whey, cow whey, albumin «Urda» cheese recipe, technological scheme

\section{Вступ}

Сири - високопоживні білкові продукти, які одержують з молока шляхом його згортання і оброблення. Вони зберігають всі основні поживні речовини молока за винятком вуглеводів. У молоці вміст жиру складає в середньому $3,4 \ldots 3,8 \%$, білка $-3,0 \ldots 3,3 \%$, а у сирах аналогічні показники становлять відповідно $20 \ldots 30 \%$ та 20...25\% (Dilanjan, 1984; Davydova, 2004). Сири $є$ концентрованими харчовими продуктами, які володіють високою калорійністю i фізіологічною повноцінністю. Якість сирів оцінюють відповідно до вимог державних стандартів і технічних умов та контролюють за хімічним складом, а саме: вмістом жиру в сухій речовині, вологи і кухонної солі, а також за органолептичними показниками. Сири відрізняються між собою за особливостями технології, органолептичними показниками та зовнішніми ознаками (Krus' et al., 1992; Hramcov and Nesterenko, 2004; Kuznecov and Shiller, 2005; Dronyk and Bilyk, 2010).

Виробництво сиру «Урда» $є$ традиційним для гірських та передгірних районів нашої країни, де розводять овець. Після приготування бринзи отримують підсирну сироватку, і найраціональнішим способом іiі використання $\epsilon$ виробництво альбумінового сиру «Урда». Виготовлення такого продукту проводиться кустарно в домашніх умовах, де не існує витриманої технологічної схеми його виробництва у промислових умовах (Bilyk, 2009; Slyvka and Bilyk, 2010; Bilyk and Dronyk, 2014). За хімічним складом такий продукт може бути прирівняний до знежиреного сиру.

Виробництво сиру «Урда» у промислових умовах може зайняти вагоме місце в асортиментному ряді молочних продуктів, оскільки сир має високі біологічну цінність та смакові якості. Одержання сиру «Урда» залежить від кількості свіжої овечої молочної сироватки. Відомо, що з 10 дм овечого молока можна отримати $450 \ldots 500$ г сиру «Урда», тому що такий продукт виготовляють виключно із овечої сироватки, він $\epsilon$ значно дорожчим порівняно 3 іншими видами сиру. Однак, використавши як додаткову сировину сироватку з коров'ячого молока, можна значно здешевити вартість готового продукту, а крім того, раціонально використати вторинну сировину, що утворюється при виробництві сирів із коров'ячого і овечого молока. Проте нормативної документації для виробництва сиру «Урда» як із овечої сироватки, так і з використанням суміші овечої і коров'ячої сироваток на сьогодні не розроблено.

Мета роботи: розрахувати рецептуру та розробити технологічну схему виробництва альбумінового сиру «Урда» для промислових підприємств. 
Матеріал та методи досліджень

Для досліджень було виготовлено 3 триразовим повторенням чотири зразки сиру:

- контрольний - альбуміновий сир, виготовлений 3 сироватки овечого молока;

- варіант 1 - альбуміновий сир, виготовлений із суміші сироваток 3 овечого і коров'ячого молока у співвідношенні 1:3;

- варіант 2 - альбуміновий сир, виготовлений із суміші сироваток $з$ овечого і коров'ячого молока у співвідношенні 1:1;

- варіант 3 - альбуміновий сир, виготовлений із суміші сироваток 3 овечого і коров'ячого молока у співвідношенні 3:1.

В основі розрахунку рецептур альбумінового сиру «Урда» лежать результати проведених експериментальних досліджень, які дали можливість визначити раціональне співвідношення овечої та коров'ячої сироваток для виробництва продукту, визначити витрати сироваток на виробництво 1000 кг альбумінового сиру.

Основою для складання рецептур на продукт стали рівняння матеріального балансу [Учет], які для альбумінового сиру мають такий вигляд:

Ma.c. $=$ Мо.с. + Мк.с. - Мосв.с.

де Ма.с., Мо.с., Мк.с., Мосв.с. - маса альбумінового сиру, овечої сироватки, коров'ячої сироватки, освітленої сироватки, відповідно, кг;

Правильність рецептурних розрахунків підтверджується рядом аналогічних результатів, отриманих в процесі кількаразових виробок продукту в лабораторних умовах кафедри технології молока і молочних продуктів ЛНУВтаБТ імені С.3. Гжицького, у фермерських господарствах СВС «Сервіс» с. Костичани та с. Малинівка Новоселицького району Чернівецької області та у виробничих умовах ПАТ «Ковельмолоко» в м. Ковелі Волинської області.

Основною сировиною для виробництва альбумінового сиру «Урда» є молочні сироватки з овечого i коров'ячого молока, отримані при виробництві сиру бринза. Молочну сироватку досліджували за основними органолептичними та фізико-хімічними показниками.

\section{Результати та їх обговорення}

Отримані в результаті проведених дослідів та експериментів дані свідчать про достовірність рецептурних розрахунків, правильність вибору режимів пастеризації овечої та коров'ячої сироваток, вибору способу виділення білків із сироваток в технології виробництва альбумінового сиру «Урда», визначення параметрів пресування сирної маси і дають можливість стверджувати, що мінімальним терміном зберігання сиру, при якому гарантується збереження всіх основних органолептичних, фізико-хімічних, мікробіологічних та біохімічних показників, є термін 5 діб.

Остаточні рецептури (на 1000 кг продукту без урахування втрат) для виробництва альбумінового сиру «Урда» наведені у табл. 1.
Табличя 1

Рецептура на виробництво альбумінового сиру «Урда», кг на 1000 кг готового продукту (без врахування втрат)

\begin{tabular}{|l|c|c|c|c|}
\hline \multicolumn{1}{|c|}{ Сировина } & \multicolumn{4}{|c|}{ Маса сировини, кг } \\
\cline { 2 - 5 } & Контроль & $\begin{array}{c}\text { Варіант } \\
1\end{array}$ & $\begin{array}{c}\text { Варіант } \\
2\end{array}$ & $\begin{array}{c}\text { Варіант } \\
3\end{array}$ \\
\hline $\begin{array}{l}\text { Сироватка 3 } \\
\text { овечого молока, } \\
\text { кг }\end{array}$ & 18450 & 4610 & 9220 & 13840 \\
\hline $\begin{array}{l}\text { Сироватка 3 } \\
\text { коров'ячого } \\
\text { молока, кг }\end{array}$ & - & 21440 & 14290 & 7150 \\
\hline Вихід продукту, кг & 1000,0 & 1000,0 & 1000,0 & 1000,0 \\
\hline
\end{tabular}

Одним 3 перших кроків при розробці технології виробництва продукту $є$ технологічна діаграма, що показує основні технологічні операції та їх характеристику. Нами розроблена технологічна схема виробництва сиру «Урда» для молокопереробних підприємств (рис. 1 і 2).

За органолептичними показниками сироватка повинна бути однорідною рідиною солом'яно-жовтого кольору, без сторонніх домішок. Допускається наявність білого осаду. Молочна сироватка повинна мати чистий, властивий сироватці смак і запах, без сторонніх присмаків і запахів. Густина має бути не нижча 1023 кг $/ \mathrm{m}^{3}$ і кислотність не вище $25^{\circ} \mathrm{T}$.

3 метою встановлення відповідності сировини вимогам чинної документації, в лабораторії приймального відділення підприємства проводять оцінку якості молочних сироваток. Приймання коров'ячої та овечої сироваток передбачають окремо. Для визначення кількості сироватки використовують лічильник. Прийняту сировину подають на систему фільтрів. Після холодного очищення молочні сироватки поступають на пластинчастий охолоджувач і негайно охолоджуються до температури $(4 \pm 2){ }^{\circ} \mathrm{C}$. Охолоджені сироватки направляють на зберігання у резервуари з сорочками охолодження, де підтримується така ж температура. Охолодження здійснюють з метою припинення розмноження мікроорганізмів, які потрапляють в сироватку при транспортуванні і прийманні. Охолоджені сироватки зберігають якість протягом 6 годин. При зберіганні понад 6 годин сироватка набуває вад смаку та консистенції.

При виборі способу виробництва необхідно передбачити найбільш повну автоматизацію і механізацію процесу, використання потокових ліній, отримання продукту високої якості, зниження виробничих витрат, максимальну ізоляцію продукту від навколишнього середовища для запобігання попадання мікроорганізмів і радіоактивних речовин.

Молочні сироватки, які призначені для сепарування, з резервуарів відцентровими насосами подають на пластинчасту пастеризаційно-охолоджувальну установку, де вони підігріваються до температури сепарування, звідки направляються на сепараторвершковідділювач. Оптимальною температурою сепарування вважається $35 \ldots 40{ }^{\circ} \mathrm{C}$. 


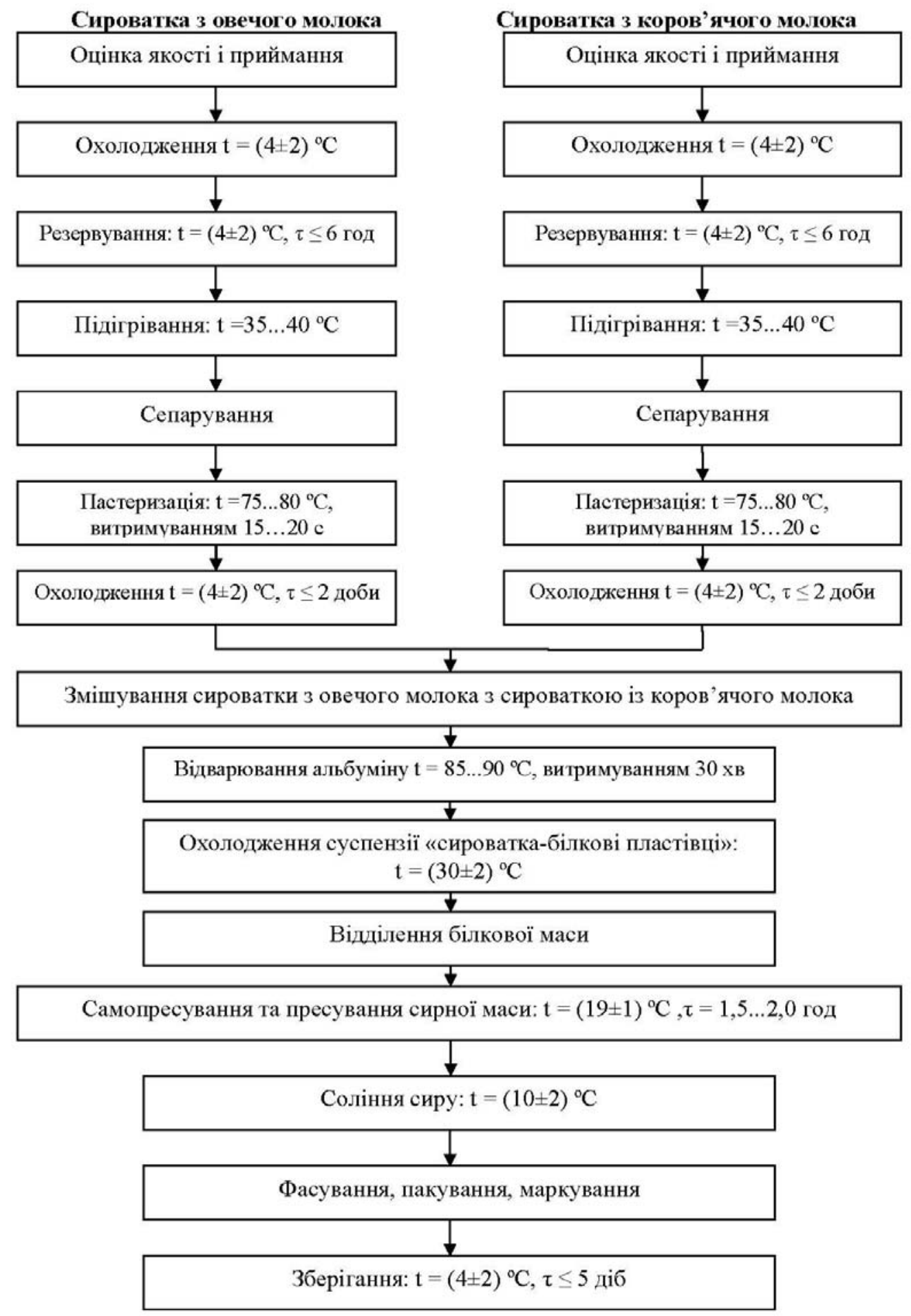

Рис. 1. Технологічна схема виробництва альбумінового сиру «Урда»

Сепарування сироватки при температурі нижче ніж $35^{\circ} \mathrm{C}$ зменшує продуктивність сепаратора, підвищує в'язкість вершків і втрати жиру в сироватку. При температурі понад $35^{\circ} \mathrm{C}$ молочний жир в молочній сироватці перебуває у розплавленому стані (температура плавлення $28 \ldots 34{ }^{\circ} \mathrm{C}$ ), це зменшує в'язкість сироватки і вершків, що полегшує сепарування.

При підвищенні температури сепарування в'язкість сироватки зменшується, умови сепарування покращуються. Найбільш різке падіння в'язкості спостерігається при нагріванні сироватки до температури
$40 \ldots 45^{\circ} \mathrm{C}$, подальше нагрівання приводить до незначного зменшення в'язкості і збільшення енергетичних затрат на нагрівання сироватки, тому температура сепарування $35 \ldots 40{ }^{\circ} \mathrm{C}$ вважається оптимальною. Крім того, підвищення температури сепарування призводить до спінювання вершків і молочної сироватки, подрібнення жирових кульок і збільшення втрат у сироватку, погіршуються умови праці.

Знежирені молочні сироватки після сепарування поступають на пластинчасту пастеризаційноохолоджувальну установку в секцію пастеризації. 


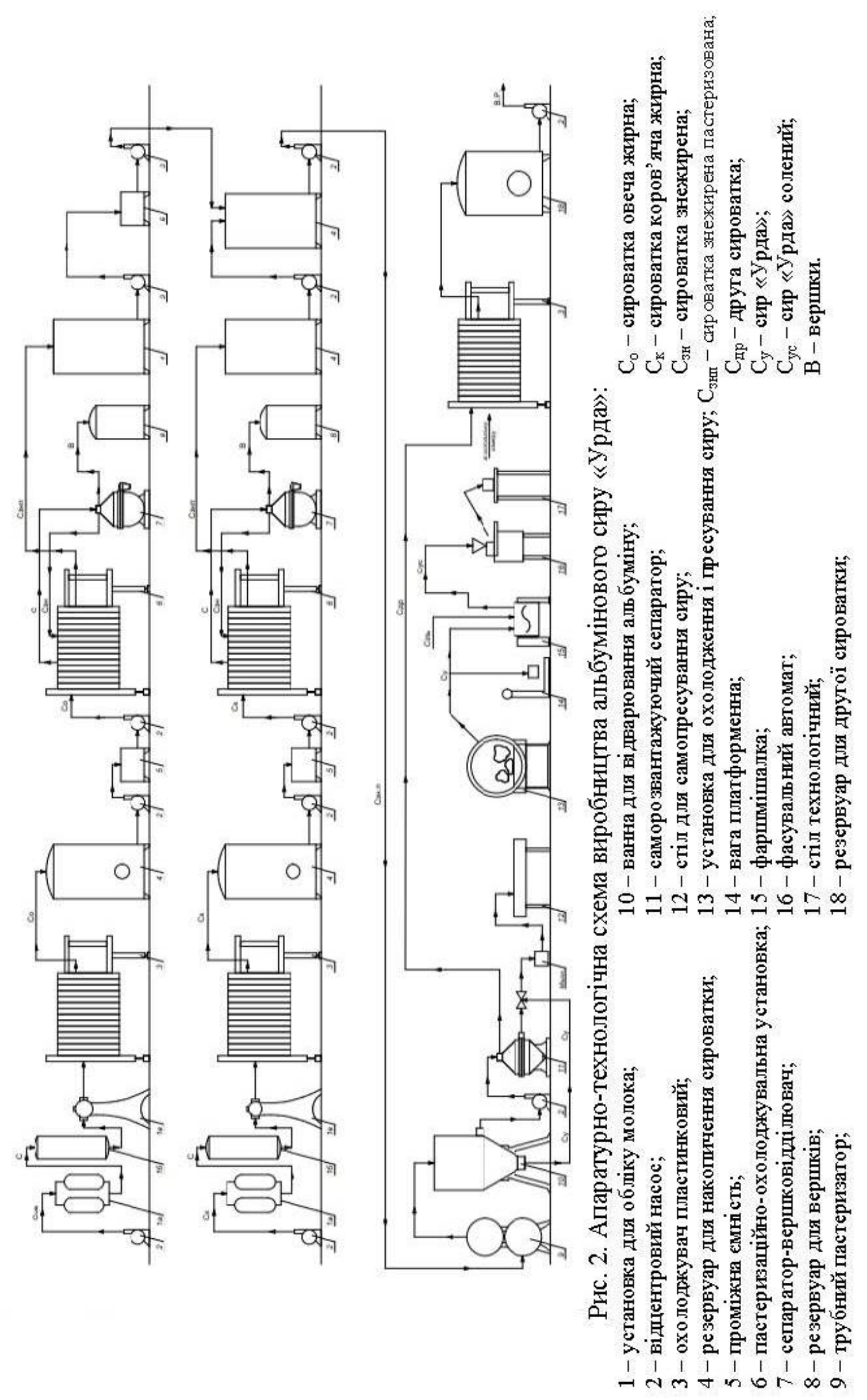


Пастеризацію здійснюють для знищення патогенної мікрофлори, інактивації ферментів і отримання продукту, безпечного для споживання в санітарногігієнічному відношенні, а також для зниження загального бактеріального обсіменіння і знищення мікроорганізмів, що призводить до псування сироватки.

Основним критерієм надійності пастеризації є такий режим, який забезпечує знищення найбільш стійкого з патогенних мікроорганізмів - туберкульозної палички і руйнування ферменту фосфатази.

За розробленою технологічною схемою для сироваток обрано режим пастеризації $72 \ldots 74{ }^{\circ} \mathrm{C}, 3$ витримуванням $15 \ldots 20$ с. Цей режим забезпечує санітарногігієнічну надійність знищення мікроорганізмів (до $99,98 \%$ ), в тому числі й туберкульозної палички. При такій температурі не виникає глибоких фізикохімічних змін молочних сироваток і максимально зберігаються їх харчова та біологічна цінність. Крім того, при пастеризації підсирних сироваток інактивуються залишки молокозсідального ферменту, присутність якого при подальшій переробці молочних сироваток є небажаною.

Пастеризовані сироватки охолоджують на тій же установці до температури $\left(4 \pm 2{ }^{\circ} \mathrm{C}\right) 3$ можливим витримуванням до 2-х діб. Далі сироватки з овечого і коров'ячого молока подають у проміжний резервуар для змішування.

Після змішування обох сироваток 3 проміжного резервуару відцентровим насосом суміш молочних сироваток поступає на трубний пастеризатор, де підігрівається до температури $85 . .90{ }^{\circ} \mathrm{C}$ і направляється у альбумінну ванну для відварювання альбуміну.

При вивченні теплової коагуляції білків сироватки встановлено, що максимальне виділення білків спостерігається в ізоелектричній точці альбумінової фракції сироваткових білків при кислотності $37^{\circ} \mathrm{T}$ i pH 4,55. Оптимальна температура при цьому складає $95^{\circ} \mathrm{C}$, а тривалість витримування - не менше 25 хв. Тому нами було обрано виділення сироваткових білків методом теплової коагуляції.

Після денатурації сироваткових білків відділення білкової маси може здійснюватися фільтрацією через бязь або центрифугуванням на сепараторі, який саморозвантажується. При застосуванні першого способу необхідно забезпечити найбільш повне осадження білкових пластівців на дно ванни. Для цього сироватку охолоджують до $30{ }^{\circ} \mathrm{C}$ і витримують при цій температурі протягом 1,5...2,0 год. Сироватку, яка залишилася, обережно зливають через спеціальні отвори або сифон. При застосуванні сепаратора саморозвантажуючого для отримання білкової маси сироватку 3 денатурованим білком перемішують i подають на сепаратор. Білок збирається в збірнику сепаратора, звідки відбувається його періодичне вивантаження.

Для отримання білкової маси використовують саморозвантажуючий сепаратор. 3 резервуару відцентровим насосом сироватку 3 коагульованими білками подають на сепаратор. 3 сепаратора альбуміновий сир подається у мішки і направляється на стіл для самопресування. Незалежно від виду, сири необхідно формувати швидко, не даючи можливості остигати сирній масі. При самопресуванні необхідно підтримувати температуру $18 \ldots 20^{\circ} \mathrm{C}$. Самопресування застосовують для відділення залишків сироватки від згустку та одержання сиру зі стандартним вмістом вологи. Самопресування здійснюється протягом 1,5...2,0 год.

Після самопресування альбуміновий сир «Урда» подають на установку для охолодження і пресування. Охолоджують альбуміновий сир до температури $8 \ldots 15^{\circ} \mathrm{C} .3$ установки сир поступає на фаршмішалку в яку подається суха дрібнокристалічна сіль класу «Екстра». Сіль наносять рівним шаром на поверхню сиру. При цьому способі соління проходить найбільше виведення вологи із сиру. Сіль вносять у кількості 1\% від маси альбумінового сиру.

Після соління альбуміновий сир «Урда» поступає на фасувальний апарат, де його фасують у полістиролові стаканчики або коробочки масою нетто 200 г. Фасування проводять без проміжного резервування, що запобігає вторинному бактеріальному обсіменіннню. Кожний полістироловий стаканчик або коробочку з готовим продуктом маркують фарбою, яка не змивається, за допомогою штампу, трафарету або печатної етикетки 3 позначеннями, передбаченими діючими технічними умовами на альбуміновий сир «Урда».

Транспортування сиру «Урда» 3 молочних підприємств здійснюється усіма видами критого транспорту відповідно до правил перевезення харчових продуктів, які швидко псуються, чинних на відповідному виді транспорту. Не дозволено зберігати і транспортувати альбуміновий сир «Урда» разом 3 іншими продуктами, які мають специфічний запах (копченості, риба, фрукти).

Сир «Урда» зберігають у холодильниках, холодильних камерах або у спецприміщеннях за відносної вологості повітря не більше ніж 85\% і температурі $(4 \pm 2){ }^{\circ} \mathrm{C}$.

Термін придатності альбумінового сиру «Урда» встановлено за температури зберігання $(4 \pm 2){ }^{\circ} \mathrm{C}$ протягом 5 діб.

Освітлена друга сироватка, яка отримана після відварювання альбуміну, з сепаратора поступає на пластинчастий охолоджувач, де охолоджується до температури $(4 \pm 2){ }^{\circ} \mathrm{C}$ і направляється у резервуар для накопичення, а з нього - здавальникам для реалізації.

Вершки, які отримали при сепаруванні сироватки 3 овечого та коров'ячого молока, 3 сепараторавершковідділювача направляють у резервуар для вершків для накопичення, а потім їх використовують для виробництва масла вершкового підсирного.

\section{Висновки}

Розроблена технологія альбумінового сиру «Урда» може бути впроваджена на молокопереробному підприємстві, де налагоджено випуск твердих сичужних сирів і розсольного сиру бринза. Впровадження нової технології не потребує великих виробничих площ, дороговартісного обладнання i додаткового переоснащення виробництва. Виробництво альбумінового сиру «Урда» може бути реалізовано на діючих вироб- 
ничих площах паралельно з випуском основної продукції.

Таким чином, на основі проведених досліджень запропоновано науково-обгрунтовані рецептури для виробництва альбумінового сиру «Урда»; розроблено технологічну схему виробництва продукту. Технологія альбумінового сиру «Урда» пройшла промислову апробацію на ПАТ «Ковельмолоко», м. Ковель. На продукт розроблено технічні умови ТУУ 01.4 00492990-004:2014.

\section{Бібліографічні посилання}

Davydova, E.A. (2004). Razrabotka tehnologii proizvodstva syra s termokislotnoj koaguljaciej belkov gomogenizirovannogo moloka: avtoref. diss. ... kand. tehn. nauk. Mogilev, 16 (in Russian).

Dilanjan, Z.H. (1984). Syrodelie. 3-e izd., pererabotannoe i dopolnennoe. M.: Legkaja i pishhevaja promyshlennost' (in Russian).

Krus', G.N., Kuleshova, I.M., Dunchenko, N.I. (1992). Tehnologija syra i drugih molochnyh produktov. M.: Kolos (in Russian).
Kuznecov, V.V., Shiller, G.G. (2005). Tehnologija i receptury: Spravochnik tehnologa molochnogo proizvodstva. Syry. S.-Pb: GIORD. 3 (in Russian).

Hramcov, A.G., Nesterenko, P.G. (2004). Tehnologija produktov iz molochnoj syvorotki: uchebnoe posobie. M.: DeLi print (in Russian).

Bilyk, O.Ia., Dronyk, H.V. (2014). Rozrobka tekhnolohii albuminovoho syru urda. Vostochno-evropeiskyi zhurnal peredovыkh tekhnolohyi Yzdatelstvo: Tekhnolohycheskyi tsentr (Kharkov). 10(69), 49-53 (in Ukrainian).

Bilyk, O.Ia. (2009). Osoblyvosti tekhnolohii syru urda. Naukovo-tekhnichnyi biuleten, №100, Instytut tvarynnytstva UAAN. Kh., 126-130 (in Ukrainian).

Dronyk, H.V. Bilyk, O.Ia. (2010). Pozhyvna tsinnist urdy, vyhotovlenoi v umovakh Chernivetskoi oblasti. Naukovyi visnyk NUBiP. Kyiv. 2, 318-321 (in Ukrainian).

Slyvka, N.B., Bilyk, O.Ia. (2010). Bukovynskyi syr urda - tsinnyi funktsionalnyi produkt. Zbirnyk statei II Vseukrainskoi naukovo-praktychnoi konferentsii LIET. Novitni tendentsii u kharchovykh tekhnolohiiakh ta yakist i bezpechnist produktiv. Lviv, 105108 (in Ukrainian).

Стаття надійшла до редакиії 14.02.2017 